\title{
The Race to Safety: How Private Lawmaking and Voluntary- Standard Adoption Can Inspire a Global Regime that Strengthens and Harmonizes Product Safety Standards
}

\author{
Alexandra Muir \\ Indiana University Maurer School of Law, almuir@indiana.edu
}

Follow this and additional works at: https://www.repository.law.indiana.edu/ijgls

Part of the Comparative and Foreign Law Commons, Consumer Protection Law Commons, and the International Business Commons

\section{Recommended Citation}

Muir, Alexandra (2016) "The Race to Safety: How Private Lawmaking and Voluntary-Standard Adoption Can Inspire a Global Regime that Strengthens and Harmonizes Product Safety Standards," Indiana Journal of Global Legal Studies: Vol. 23 : Iss. 1 , Article 14.

Available at: https://www.repository.law.indiana.edu/ijgls/vol23/iss1/14

This Note is brought to you for free and open access by the Law School Journals at Digital Repository @ Maurer Law. It has been accepted for inclusion in Indiana Journal of Global Legal Studies by an authorized editor of Digital Repository @ Maurer Law. For more information, please contact rvaughan@indiana.edu.

\section{$\Psi$}

JEROME HALL LAW LIBRARY

INDIANA UNIVERSITY

Maurer School of Law
Bloomineton 


\title{
The Race to Safety: How Private Lawmaking and Voluntary-Standard Adoption Can Inspire a Global Regime that Strengthens and Harmonizes Product Safety Standards
}

\begin{abstract}
ALEXANDRA MUIR*
ABSTRACT

Today's economy is dominated by global actors. Over the past few decades, transnational corporations have increased in number and importance while domestic corporations have turned to outsourcing to cut costs and increase efficiency. The globalized economy has caused a breakdown in both physical and legal boundaries, as products in international commerce move from one jurisdiction to another, often adhering to safety standards of an entirely different jurisdiction than the one in which they are sold. This breakdown raises concerns about product safety and illustrates the importance of creating a consistent products liability regime for the international market. At the same time, consumer expectations and the high visibility of these large, transnational actors have created an incentive for manufacturers to put safe products in the market. With numerous market forces in play, this Note suggests a regime that promotes private lawmaking and the adoption of voluntary standards. Such a regime has the potential to create consistent product safety standards across jurisdictions while instituting a "race to the top" among these transnational actors.
\end{abstract}

\section{INTRODUCTION}

The global economy has evolved into a complex web of transnational actors and markets that is not confined by legal or physical boundaries. This evolution can be partly attributed to the increased number and importance of transnational corporations (TNCs), whose presence has risen dramatically since the $1980 \mathrm{~s} .{ }^{1}$ Because these TNCs locate facilities

* Alexandra C. Muir, Editor-in-Chief, Indiana Journal of Global Legal Studies, Volume 23; J.D. 2016 Indiana University Maurer School of Law; B.A. 2013 Indiana

Indiana Journal of Global Legal Studies Vol. 23 \#1 (Winter 2016)

(C) Indiana University Maurer School of Law 
all over the world without regard to any legal or jurisdictional boundaries, they act as "footloose" actors who cannot be associated with any one location or home base. ${ }^{2}$ The globalized nature of TNCs raises questions about which laws and which criteria should govern their operations. ${ }^{3}$ In addition, even domestic companies have increased their outsourcing of production to other countries (and thus have lost their "domestic" status) in an effort to cut costs and increase efficiency. ${ }^{4}$ The trend of outsourcing causes domestic companies to face similar legal complexities as those experienced by TNCs, as both of these global trends have contributed to "the increased flow of capital, information, and goods across borders," which has ultimately blurred the distinction between foreign and domestic products. ${ }^{5}$

As this distinction between foreign and domestic products becomes hazy, so too does the determination of which country's law applies to these products in international commerce. ${ }^{6}$ In terms of products liability, inconsistent or conflicting requirements between nations can lead to a lack of predictable standards for manufacturers, causing uncertainty as to which laws apply. ${ }^{7}$ Because these manufacturers must mass-produce and mass-market their products internationally, they find it cumbersome, and often impossible, to comply with each nation's conflicting laws and standards. ${ }^{8}$ These conflicting requirements "not only discourage essential manufacturer planning and decision-making,

University. I would like to thank Professor Alfred C. Aman for providing me with invaluable guidance throughout this note-writing process. I would also like to thank Professor Jody L. Madeira for first introducing me to the world of products liability and for providing helpful guidance throughout the revision process.

1. Gralf-Peter Calliess, Introduction: Transnational Corporations Revisited, 18 IND. J. Global LEGAL STUD. 601, 606 (2011). The World Investment Report 2009 report explains that roughly 82,000 transnational corporations exist worldwide. Id.

2. Id. at 607 .

3. See id.; see also Kenneth W. Abbott \& Duncan Snidal, The Governance Triangle: Regulatory Standards Institutions and the Shadow of the State, in THE Politics of GLOBAL REGULATION 44, 58-59 (Walter Mattli \& Ngaire Woods eds., 2009) (claiming that the extent of national legal authority over foreign business operations remains unclear).

4. See e.g., Merrill Matthews, Companies 'Outsource' Because That's Where the Sales Are, FORBES (July 20, 2012, 3:20 PM), http://www.forbes.com/sites/merrillmatthews /2012/07/20/companies-outsource-because-thats-where-the-sales-are/ (claiming that numerous U.S. companies are opening stores, building factories and hiring people overseas because the largest growing markets are outside their domestic market).

5. U.S. Food \& DRUg ADmin., Pathway to Global Product SaFETy and Quality 2 (2011), http://www.fda.gov/downloads/AboutFDA/CentersOffices/OfficeofGlobalRegulatory OperationsandPolicy/GlobalProductPathway/UCM262528.pdf.

6. See Rebecca Korzec, Products Liability Harmonization: A Uniform Standard, 9 IUS GENTIUM 25, 25 (2003).

7. See id. at $26-27$.

8. $I d$. 
they also jeopardize product design and safety,"9 as many imported products do not adhere to the domestic safety and design regulations of the receiving country. ${ }^{10}$

While an international uniform products liability regime may appear to be the most obvious answer to the problems arising from conflicting regulatory standards, this Note goes one step further to argue for the creation of a harmonized global products liability regime that actually increases safety standards. In today's global market, it is necessary to strengthen both the certainty of which standards apply and the stringency of the product safety standards. This Note sets out to do both. Part I takes a closer look at the complexities of today's global market that give rise to this inquiry and focuses on major TNCs whose products have the potential to reach a significant portion of global consumers. Part II discusses the competitive nature of today's global market and addresses how this focus on competition has affected the agendas of transnational actors. Part III discusses the effectiveness of two private approaches to products liability laws that have the potential to increase safety standards: private lawmaking and the adoption of voluntary standards. This section addresses the strengths and weaknesses of these two approaches-private lawmaking being strong for increased safety standards but weak for harmonization, and voluntary standards being strong for harmonization but weak for increased standards. Finally, Part IV suggests how to utilize each of these approaches in such a way that will not only increase safety standards, but also harmonize these standards around the globe. This Note proposes that voluntary-standard organizations and the companies that adhere to their standards should engage in private lawmaking by entering into contractual agreements regarding safety standards; these contractual provisions will serve as baseline safety standards for the manufacturers, thereby leaving room for market forces to institute a "race to the top" for competing corporations in today's global market. In order to incentivize TNCs to enter into contractual agreements with voluntary-standard organizations, the standards developed should be sufficient for all countries around the globe, thereby giving TNCs the assurance that complying with these voluntary standards will allow their products to be sold in any market in the world.

9. Id.

10. See generally Cary Coglianese et al., Consumer Protection in an Era of Globalization, in IMPORT SAFETY: REGULATORY GOVERNANCE IN THE GLOBAL ECONOMY 1 (Cary Coglianese et al. eds., 2009), available at http://scholarship.law.upenn.edu/ faculty_scholarship/351 (detailing the risks that consumers face in today's global market). 


\section{A Closer LoOK at Today's Global MARKet: THE COMPLEXITY, RISK, AND NEED FOR A GLOBAL REGIME THAT INCREASES SAFETY STANDARDS}

The competitive nature of today's global manufacturing market creates incentives for outsourcing to locations where products can be made cheaply and in mass quantities. ${ }^{11}$ For example, China, which possesses the world's largest manufacturing workforce of 104 million people, has changed the way the entire global market operates: "China has been able to successfully alter the competitive landscape of the global marketplace by employing people in place of machines." 12 This characteristic of Chinese manufacturing produces goods at a low price, which has become known as the "China price."13 It continues to be an essential pricing factor of many global manufacturers because consumers and companies demand cheap products in the market. ${ }^{14}$ Unfortunately, the "China price" is also made possible because of China's willingness to cut costs and essentially ignore safety measures, an aspect of Chinese manufacturing that creates "unquantifiable risk factors, primarily that the products may be defective or dangerous." 15 Deficient government oversight, enforcement mechanisms riddled with corruption, and a complete failure to regulate the safety of products in production has allowed these unsafe products to enter the global market. ${ }^{16}$ This risk factor has the potential to reach consumers in countries around the globe, as China has rapidly become the world's most important trade partner. ${ }^{17}$

A close look at the trend of outsourcing and the nature of Chinese manufacturing suggests that globalization has played a role in placing consumers at risk from dangerous or defective products. In order to mitigate this risk, a globalized products liability regime must be created in order to ensure the safety of consumers around the globe. The law of products liability has two functions: first, to compensate injured victims,

11. See Matthews, supra note 4.

12. Stephanie Glynn, Note, Toxic Toys and Dangerous Drywall: Holding Foreign Manufacturers Liable for Defective Products-The Fund Concept, 26 EMORY INT'L L. REV. 317,325 (2012).

13. See id. at 324 (quoting AleXandra HaRney, The ChINA PRICE 2 (2008)).

14. Cf. id. at 326 (arguing that the "China price" results from the demands of U.S. consumers and companies for cheap goods).

15. $I d$.

16. See id. at $327-29$.

17. See China Eclipses U.S. as Biggest Trading Nation, BLOOMBERG BUSINESS (Feb. 10, 2013, 11:01 AM), http://www.bloomberg.com/news/2013-02-09/china-passes-u-s-tobecome-the-world-s-biggest-trading-nation.html ("For so many countries around the world, China is becoming rapidly the most important bilateral trade partner .... At this kind of pace by the end of the decade many European countries will be doing more individual trade with China than with bilateral partners in Europe."). 
and second, to act as a gate-keeper to ensure the safety of products entering the market. ${ }^{18}$ This Note focuses on the second functionensuring the safety of products in the market-because the possibility of creating a harmonized global regime that increases safety standards is much more probable with respect to this function of products liability law. There are two reasons for this. First, a focus on the first function of products liability law-compensating injured victims-would not touch off the race to the top that this proposal aims to achieve: "[T] here are many policy areas, such as strict product liability, in which free trade and economic competition would not generate a race-to-the-top dynamic. Generally, race-to-the-top dynamics are likely to be limited to standards concerning traded goods and services . ..."19 In contrast, focusing on the second function of products liability law will concern traded goods within the market and will therefore have a better likelihood of resulting in a race-to-the-top dynamic. The second reason for focusing on safety standards is that the legal nuances of each market are so diverse that a harmonized regime for compensating victims is not a probable solution. For example, even though in 1985 the European Union adopted the Product Liability Directive, which closely mirrors many concepts of the U.S. regime, their system continues to contrast starkly with the U.S. regime as litigation remains rare, class actions are unavailable in most member states, and the massive damage awards common in the United States are altogether absent. ${ }^{20}$ These stark differences, existent even in a jurisdiction that attempted to mirror the U.S. regime in many ways, illustrates that a global regime encompassing the compensation of injured victims is not a feasible solution.

A closer look at manufacturing in Japan further illustrates why the global regime must focus on safety standards rather than compensation. Japan's products liability regime has evolved into one that is much more stable and honest than the regime in China: Japan voluntarily adopted products liability laws based on strict liability in 1993, which has led to improvements such as more detailed warnings and instructions for products, more legal review, products liability insurance, and more detailed contracts with manufacturers and consumers. ${ }^{21}$ Notably, these improvements have created a safer environment for consumers and an

18. Geraint G. Howells, The Relationship Between Product Liability and Product Safety-Understanding a Necessary Element in European Product Liability Through a Comparison with the U.S. Position, 39 WASHBURN L.J. 305, 307 (2000).

19. R. Daniel Keleman \& Eric C. Sibbitt, The Globalization of American Law, 58 INT'L ORG. 103, 108 (2004).

20. See id. at $120-21$.

21. See id, at $129-30$. 
easier path to litigation, but they have not resolved all challenges for global corporations operating in Japan. As illustrated by the 2009 Toyota acceleration recall, globalization continues to jeopardize product safety. This recall, one of the largest in the history of the automotive industry, ended in a settlement that amounted to more than a third of Toyota's 2013 profit. ${ }^{22}$ Discussing the massive recall, Akio Toyoda, Toyota's president and CEO, stated that the recall was the result of Toyota's "failure to connect the dots' as the company was receiving information about the product failures from North America and Europe, but the information wasn't finding it's [sic] way back to Corporate Japan and the right department ...."23 This example illustrates that even the development of a strict products liability regime cannot resolve all the risks inherent in a global manufacturing operation, and thus indicates that a regime focusing on safety standards may better address the complexities within today's market.

Recent recall statistics provide further evidence of the inherent risks of the globalized market. In 2010, product recalls were at record numbers and had grown every year since $2004 .{ }^{24}$ In 2013,22 million vehicles were recalled, the highest number the market had seen in nearly nine years. ${ }^{25}$ These statistics demonstrate that the products liability regime currently in place is no longer protecting consumers in the globalized market. It is true that manufacturers often voluntarily recall defective products before more harm can result, allowing those manufacturers to avoid costly litigation and high damage awards. However, the mere existence of these defective products in the market is still troubling-after all, many consumers will be harmed by the defective product before a recall is initiated. Whether this increase in recalls is caused by a lack of regulatory uniformity between importing and exporting nations or a lack of communication within the supply chain, it has become evident that consumer safety is at risk and that something must be done, on a global scale, to lessen this risk. Recall rates indicate that today's safety standards may not be high enough, so

22. Danielle Douglas \& Michael A. Fletcher, Toyota Reaches $\$ 1.2$ Billion Settlement to End Probe of Accelerator Problems, Wash. PosT (Mar. 19, 2014), http://www.washingtonpost.com/business/economy/toyota-reaches-12-billion-settlement-toend-criminal-probe/2014/03/19/5738a3c4-af69-11e3-9627-c65021d6d572_story.html.

23. Randall Goodden, Understanding the Continuous Cause of Product Recalls \& Product Liability Lawsuits, INDUSTRYWEEK (Aug. 7, 2010), http://www.industryweek.com/ companies-amp-executives/understanding-continuous-cause-product-recalls-productliability-lawsuits.

24. See id.

25. See Cheryl Jensen, Safety Agency Says 22 Million Vehicles Recalled in 2013, N.Y. TIMES (Feb. 3, 2014), http://www.nytimes.com/2014/02/04/automobiles/safety-agency-says22-million-vehicles-recalled-in-2013.html?_r=1. 
a regime that inspires a race to the top among manufacturers is desirable for consumer protection. Moreover, the lack of uniformity among nations has been a constant cause of frustration for manufacturers, so a regime that harmonizes standards across the globe would provide certainty and allow manufacturers to comply more easily with the legal requirements of their industry. ${ }^{26}$

In order to ensure the safety of consumers around the globe, safety norms must be created and harmonized, but they also need to be implemented and enforced. This Note focuses on two private approaches to products liability in order to illustrate the role of private actors in today's globalized market: "In local, transnational, and international law-making processes ... the role of non-legal actors . . often appears to dominate ... the production or adoption of new legal categories and concepts." 27 This proposal is geared primarily toward major manufacturing companies, as the circumstances surrounding these companies provide the ideal setting for the adoption and enforcement of a safety standard regime. First, a global regime is more likely to have success among these major global actors. Mauro Zamboni notes that globalization processes can fail for a number of reasons: global actors can reject certain global legal categories, for example, or the circulation of legal models can be hindered by unique conditions within each legal market. ${ }^{28}$ For these major global actors, however, their success relies on the globalization of capital and products; these companies rely on the ability of their products to be marketed and sold around the globe in a wide range of markets. Because these companies depend on globalization of their products, they cannot afford to reject the globalization processes. In addition, because the products manufactured by each of these companies have the highest potential to reach a large number of consumers around the globe, ${ }^{29}$ a regime that increases safety standards for these companies will have the potential to protect more consumers in the market. Finally, the proposed regime relies entirely on private, voluntary lawmaking, which can only work among corporations

26. See Korzec, supra note 6, at 25-33 (arguing that a uniform approach is the most effective means of creating safer products in a global economy).

27. Mauro Zamboni, Globalization and Law-Making: Time to Shift a Legal Theory's Paradigm, 1 LEGISPRUDENCE 125, 134 (2007).

28. See id. at 136.

29. See, e.g., Figures: Market/Toyota Sales and Production, ToYota GLobaL SITE, http://www.toyota-global.com/company/profile/figures/ (last visited Nov. 6, 2015) (illustrating the global reach of Toyota, the world's largest car manufacturer, into North America, Latin America, Europe, Africa, Asia, and Oceania). 
that have the most at stake, as they tend to adopt voluntary initiatives in order to build credibility in the eyes of the global society. ${ }^{30}$

\section{Competitive Advantage: The Driving Force in Today's Global MARKET AND THE BEACON OF HOPE FOR AN INCREASE IN SAFETY STANDARDS}

The competitive nature of today's global market and the role competition plays in the decision-making process of each global manufacturer provide the foundation for the success of private lawmaking as a regulatory regime. Because these large, global corporations live and die by the actions of consumers, they are constantly competing with one another for consumer approval and loyalty. ${ }^{31}$ This competition leads these global corporations to adopt selfregulating standards that impact not only their own operations but also the operations of their supply chain. ${ }^{32}$ This section proposes that in today's global market, the risks created by the modern risk society ${ }^{33}$ are defined by consumers, who have become the driving force of competition among global manufacturers. Consumer-defined risks have caused a shift in the way global manufacturers operate, leading to an increase in private lawmaking and self-regulation. While the discussion of corporate self-regulation has largely been contained to areas of labor, environmental governance, and human rights law, ${ }^{34}$ this section proposes that private lawmaking and regulation also have a place among global products liability law-specifically, product safety standards.

Ulrich Beck's theory of the modern risk society proposes that modern society organizes itself according to risk through a process called "reflexive modernization," meaning that the logic of risk production dominates the logic of wealth production, thereby allowing risk to be the driving force behind the actions of those in modern

30. See Kevin T. Jackson, Global Corporate Governance: Soft Law and Reputational Accountability, 35 BROOK. J. INT'L L. 41, 45-46 (2010).

31. See id. at 86 (discussing the impact of citizen campaigns on the voluntary actions of global corporations, as the latter pressures transnational companies to behave with increased responsibility).

32. See id.

33. The term "risk society" was coined by German sociologist Ulrich Beck. See generally ULRICH BECK, RISK SOCIETY: TOWARDS A NEW MODERNITY (Mark Ritter trans., Sage Publications 1992) (establishing risk as the driving force behind the actions and decisions made in modern society).

34. See Jackson, supra note 30 , at 86 (citing David Vogel, Private Global Business Regulation, 11 ANN. REV.POL. SCI. 261, 268 (2008)). 
society. ${ }^{35}$ Beck argues that, in modern society, human activity creates manufactured risks, and these risks, which transcend class and geographical boundaries, are what guide the actions and inactions of actors in the market. ${ }^{36}$ Beck states that market actors use each other to define risk: "One hazardous product might be defended by dramatizing the risks of the [other hazardous products]." 37 Beck suggests that the actors who get to define risk hold all the power in the market, as they defend their own risks by exposing the risks caused by others. ${ }^{38}$ Beck wrote in the early 1990 s, but now, two decades later, the introduction of social media has made disasters arising from defective products much more visible to consumers, as knowledge of such disasters and subsequent negative media coverage can spread worldwide in a matter of seconds. ${ }^{39}$ Because consumers are now empowered with information and the ability to spread information around the globe almost instantly, the power to define risk now lies in the hands of consumers.

The fact that consumers now hold the power to define risk has changed the way global manufacturers operate, as they are now at the mercy of consumers' risk definitions and find themselves competing with one another to improve product safety and thus improve their own risk definition among consumers. ${ }^{40}$ This aspect of today's global market was known to Beck, as illustrated by his discussion of the consumer impact of these risk definitions. Beck states that risks are subject to public criticism, ${ }^{41}$ as "every socially recognized 'cause' [of a risk] comes under massive pressure for change," and "[e]ven if this public pressure is fended off, sales drop, markets collapse and the 'trust' of customers has to be won back and strengthened by large, expensive advertising campaigns." 42 Beck writes about the impact of risk on consumer actions with the understanding that the manufacturers are defining the risk; today, however, consumer actions can have an even bigger effect, depending on how consumers choose to define the risk: "[T] he degree to which consumers will punish manufacturers for unsafe products or reward them for safe products clearly depends on the information that consumers have about product safety, and they have many sources of

35. See BECK, supra note 33 , at 12-13.

36. See id. at 21-24.

37. Id. at 31 .

38. See id.

39. See The Toyota Recall: A Public-Relations Disaster? NEwSWEEK (Feb. 2, 2010, 7:00

PM), http://www.newsweek.com/toyota-recall-public-relations-disaster-74961.

40. See A. Mitchell Polinsky \& Steven Shavell, The Uneasy Case for Product Liability, 123 HARV. L. REV. 1437, 1443 (2010).

41. BECK, supra note 33 , at 13.

42. Id. at 32 . 
such information available to them." 43 The degree to which consumers will punish or reward manufacturers depends on the risk definitions created within the consumer market, and the punishment or reward will be the consumers' tendencies to purchase products with a low-risk definition and avoid products with a high-risk definition. For this reason, manufacturers must get out ahead of these consumer-generated risk definitions to define themselves as low-risk manufacturers as compared to their competitors, so they may maintain their competitive advantage within the market. ${ }^{44}$

Risk definitions are not the only source of competition within today's global market. Rather, the competitive nature of today's market creates a conflicting dynamic, as manufactures must provide cheap products for the market and simultaneously avoid any negative risk definitions resulting from outsourcing of labor and production. For example, manufacturers are attracted to production in China because it offers a competitive advantage in terms of cheap labor and production costs, but the attractiveness of this strategy has lessened in recent years. ${ }^{45}$ One reason for this is that, in the global economy, "goods produced in one country might result in liability and regulatory concerns in another country where they are sold and used." 46 New risks have emerged for those who choose to enter their products into the worldwide market, causing companies to respond not to the risk of disaster, but to the risk of legal liability. ${ }^{47}$ The process of learning from disaster ${ }^{48}$ certainly still has a place in today's global market:

The recent Toyota [acceleration recall] was a major wake-up call for manufacturers, as was the BP disaster

43. Polinsky \& Shavell, supra note 40 , at $1445-46$.

44. Consumer-defined risks do not impact all markets in the world, and specifically do not impact markets where consumers are not as informed or knowledgeable about the existence of risk. For example, in 2013, three of the world's largest car manufacturers were accused of selling sub-standard vehicles, which did not meet the most basic safety standards, to consumers in Latin America. Because the consumers in this market are less likely to have their own risk definitions, manufacturers can take advantage of their vulnerability by selling sub-standard products. See Jo Confino, Car Manufacturers Accused of Lower Safety Standards in Latin America, THE GuARDIAN (July 24, 2013, 10:16 AM), http://www.theguardian.com/sustainable-business/blog/car-manufacturers-criticisedsafety-latin-america.

45. George J. Siedel \& Helena Haapio, Using Proactive Law for Competitive Advantage, 47 AM. BUS. L.J. 641, 645 (2010).

46. Id.

47. See id.

48. See generally LEARNING FROM DISASTER: RISK MANAGEMENT AFTER BHOPAL (Sheila Jasanoff ed., 1994) (discussing the process by which companies respond to and learn from large industrial disasters in such a way that improves the safety of their processes). 
a wake-up call for corporate management practices, and as is usually the case, it many times takes a high profile disaster for others to finally pay attention to what needs to be done within their own companies. ${ }^{49}$

Today, however, disasters have proven to be so detrimental to a manufacturer's competitive advantage that companies ${ }^{50}$ can no longer afford the risk. Past disasters also demonstrate that the consumer and investor response is to stop buying products from and investing in companies that place consumers in harm's way. ${ }^{51}$ For example, Takata Corporation, which recently received international attention for producing faulty airbags for many of the world's major automobile manufacturers, experienced a record plunge in Tokyo trading after Toyota advised U.S. consumers about the faulty airbags. ${ }^{52}$ The company's stock fell by 23 percent, the biggest drop since the company was listed in 2006, and it expects to suffer a net loss of $\$ 226$ million..$^{53}$

When these high-visibility corporations create a defective product with the potential to compromise the health and safety of millions of consumers around the globe, they risk taking a significant hit, whether that be entering a settlement for a third of the company's yearly profit like Toyota ${ }^{54}$ or dropping in sales and investment like Takata ${ }^{55}$ and Odwalla.56 The high visibility of certain manufacturers and their products in the global market (owing largely to the existence of the Internet) creates a much larger risk for the company when it introduces dangerous products into the market. Major manufacturers are learning that they can no longer afford these risks if they want to maintain a favorable risk definition among consumers and thus maintain

49. Goodden, supra note 23.

50. The impact of market forces and competitive advantage is important for companies that manufacture widely sold products with salient risks; however, market forces do not play as large of a role for companies who produce products that are not widely sold, where the risk of harm is unknown or not as widely publicized. In these scenarios, market forces are unlikely to provide incentives to increase product safety. See Polinsky \& Shavell, supra note 40 , at 1449 .

51. See, e.g., id. at 1444 ("Odwalla's sales of natural juices declined by $90 \%$ in 1996 after one person died and sixty others were made ill by consuming some of its products containing E. coli bacteria." (citations omitted)).

52. See Ma Jie \& Yuki Hagiwara, Takata Falls by Record Amid Escalating Air.Bag Recall, BLOOMBERG Business (Oct. 21, 2014, 12:36 AM), http://www.bloomberg.com/ news/articles/2014-10-21/takata-drops-by-record-in-tokyo-trading-as-air-bag-recall-widens.

53. Id.

54. See Douglas \& Fletcher, supra note 22.

55. See Jie \& Hagiwara, supra note 52.

56. See Polinsky \& Shavell, supra note 40 , at 1444. 
competitive advantage in the market. ${ }^{57}$ The desire of manufacturers to please consumers by avoiding risk has the potential to spur private lawmaking, which can ultimately improve safety standards. ${ }^{58}$ The next section analyzes private lawmaking within today's global market and its ability to increase safety standards among global actors. Specifically, it examines the adoption of voluntary standards as a way to harmonize a potential global products liability regime.

\section{PRIVATE APPROACHES to PRODUCTS LIABILITY AND THEIR POTENTIAL TO INCREASE SAFETY STANDARDS AND ACHIEVE HARMONIZATION}

Private lawmaking is the process by which a private group makes rules that can govern much larger groups, and the idea encompasses the ability of private actors to make law that governs corporate, commercial, and consumer behavior. ${ }^{59}$ In Section A, I refer to "private lawmaking" as the process by which the manufacturer, as the private actor, makes rules to govern itself and its suppliers and enforces those rules through contractual drafting. In utilizing this lawmaking process, these private actors have the ability to impose rules on themselves that are in fact more stringent than the regulatory requirements enforced by government agencies. In Section B, I discuss voluntary standards, which are another form of private lawmaking in which private institutions draft and publish standards that are then adopted by companies on a voluntary basis without government enforcement. 60

\section{A. Global Products Liability Through Private Lawmaking: Good for Increasing Safety Standards, Not So Good for Harmonization}

When manufacturers engage in private lawmaking, they take advantage of a lawmaking regime that utilizes various actors in the market: consumer forces dictate consumer expectations to manufacturers, who may include provisions into their contracts based on these consumer expectations; the media can hold these companies

57. See id. at 1443 .

58. This potential improvement in safety standards is contained within the realm of large volume, high visibility manufacturers who "have more to lose if consumers think that their products are dangerous and more to gain if consumers believe that their products are safe, giving them a greater inventive to invest in product safety." Id. at 1449 .

59. See David V. Snyder, Private Lawmaking, 64 OHIO ST. L.J. 371, 371 (2003).

60. See Joseph J. Lazzara, Safeguarding: Are ANSI Standards Really Voluntary?, ANSI (Dec. 2004), http://www.ansi.org/news_publications/other_documents/safeguarding. aspx?menuid=7 (discussing the process of voluntary standards creation and adoption for the American National Standards Institute, which is a private voluntary standard organization in the United States). 
accountable for accidents such as disasters and mass recall events that may expose a lack of adherence to these privately made standards; and the contractual provisions created through private lawmaking allow the law to compel the manufacturers to do what they say they will.

First, consumers are quickly becoming the dominant actor in today's global market, as they are the ones that will ultimately be affected by and expose the manufacturer for a lack of compliance with safety standards. ${ }^{61}$ Ulrich Beck notes that victims in global risk positions, which, in terms of products liability, means consumers whose health and safety can be compromised by the actions of manufacturers, become unified.62 This unification of consumers spurs the need to "find and enforce solutions to the self-inflicted endangering that crosses all borders"63 - the "self-inflicting endangering" referring to manufactured risks.

Second, private lawmaking utilizes manufacturers within the market. The unified consumer 64 market force provides an "incentive [for manufacturers] to improve product safety, for if consumers believe that the risk of a product is high, they will either avoid buying the product or will not pay as much for it as they otherwise would."65 In today's global market, which has utilized technology to become more unified than ever, corporations must "begin partnering with the rising tide of customers who can now demand new standards for corporate behavior and a higher commitment to purpose, not just profit."66 Today, the role of private actors and manufacturers in creating and enforcing international law has become increasingly important. ${ }^{67}$ One reason for this is the inability of state regulation to act swiftly in response to disasters. Regulatory agencies often have limited resources that only allow them to address a few safety problems at one time, which

61. See Mathias Reimann, Liability for Defective Products at the Beginning of the Twenty-First Century: Emergence of a Worldwide Standard?, 51 AM. J. CoMP. L. 751, 75960 (2003).

62. See BECK, supra note 33, at 47 ("[T] he risk society produces . . . a new type of community of the endangered ... . [It] develops a tendency to unify the victims in global risk positions.").

63. Id. at $47-48$.

64. By "unified consumers," I mean consumers in global risk positions who have access to information regarding these risks and the ability to impact the market through their purchase or avoidance of high-risk products. Consumers become unified with respect to specific products that pose a risk to health and safety. $C f$. id.

65. Polinsky \& Shavell, supra note 40 , at 1443.

66. Simon Mainwaring, The New Power of Consumers to Influence Brands, FORBES (Sept. 7, 2011, 1:46 PM), http://www.forbes.com/sites/simonmainwaring/2011/09/07/thenew-power-of-consumers-to-influence-brands/.

67. See Paul B. Stephan, Privatizing International Law, 97 VA. L. REv. 1573, 1574-75 (2011). 
essentially means that, as one safety problem is addressed, many others go by the wayside. ${ }^{68}$ As safety risks become known to the consumer populace, manufacturers must act independently of regulatory agencies in order to maintain their positive reputation and favorable risk definition among consumers. The debate over the safety of bisphenol A (BPA), a chemical used in plastic manufacturing, provides an excellent illustration of the influence consumers have on today's market. ${ }^{69}$ After putting a significant amount of time and money into research, agencies of six different governments and various scientific studies have determined that BPA is safe as used by today's market; nevertheless, large companies such as Wal-Mart and Toys "R" Us have refused to sell baby bottles made with BPA. ${ }^{70}$ These retailers did not base their decisions on safety only, but rather on "what will or will not motivate consumers." 71 By banning the use of BPA in products, these retailers have engaged in private lawmaking that imposes harsher restrictions on their operation than the law requires.

The final two actors that private lawmaking utilizes-the media and law enforcement-ensure that these companies actually adhere to these self-created standards. Product liability cases already receive much attention from the media, ${ }^{72}$ and the use of social media has allowed consumers to strongly influence business practices by exposing the negative and positive actions of companies. ${ }^{73}$ In terms of enforcement, the nature of private lawmaking through contractual obligations with buyers, suppliers, or retailers allows legal enforcement to exist when one party breaches a duty required by the contract. When a company simply imposes safety standards on itself (such as Wal-Mart and Toys "R" Us refusing to sell BPA products), consumer forces hold the companies accountable by exposing any lack of compliance with their claimed standards. ${ }^{74}$

The recent actions of two global manufacturers, Toyota and Mattel, illustrate the trend of private lawmaking in the global market. First, not long after the massive acceleration recall that permeated the Internet and traditional media, Toyota announced that it plans to be the

68. See Teresa Moran Schwartz, The Role of Federal Safety Regulations in Products Liability Actions, 41 VAND. L. REV. 1121, 1151-52 (1988).

69. See Pat Rizzuto, Bisphenol A Debate Transforms Toxicology as Market Forces Outpace Research Efforts, 41 PROD. SAFETY \& LIAB. REP. 1041 (2013), available at BLOOMBERG LAW.

70. See id.

71. Id.

72. Polinsky \& Shavell, supra note 40 , at 1439.

73. See Mainwaring, supra note 66.

74. See id. ("Social media gives [consumers] . . . a means to punish irresponsible corporate behaviors."). 
first mainstream automaker to offer high-tech crash avoidance systems on all of its 2017 models - an announcement made at a safety conference in 2014. 75 The reasoning behind Toyota's actions are clear: "Automakers are competing on safety, so they're using safety technology as a way to get a leg up on their competitors."76 Toyota's announcement could spur actions from other automakers to meet these same safety requirements, ${ }^{77}$ ultimately producing an increase in safety standards free from government mandate. While Toyota has just recently made this announcement, the goal is that by 2017 , these safety requirements will be placed in all of Toyota's contracts with its suppliers and retailers, thus creating an enforceable safety standard. This example illustrates the power of the market, driven by competitive advantage, to increase safety standards solely by a company's private actions.

The second example concerns Mattel, an American toy manufacturer that has also engaged in private lawmaking in recent years. In light of massive recalls for Chinese-made products that contained high levels of lead in 2007, Mattel instigated a three-stage safety check for lead paint, restructured its quality oversight by adding a new product policy and audit program, and created a corporate responsibility group. ${ }^{78}$ While this private lawmaking regime ensures that Mattel will perform due diligence in inspecting these Chinese imports, any contract between Mattel and its Chinese importer may contain product specification provisions and safety standards that the Chinese manufacturer or supplier must abide by, since any act of noncompliance by the Chinese exporters will result in a breach of contract and an ultimate claim against that Chinese entity. ${ }^{79}$ The act of writing these heightened standards into contractual provisions also expands the reach of the increased safety regime and can result in increased standards, not just in one country or for one company, but in all companies connected by the global chain, regardless of location.

Private lawmaking does have the potential to increase safety standards on a global scale, but it cannot provide a global solution to the product liability complexities in today's market. One reason is that while incentives provided by market forces are strong for widely sold products, they are not nearly as strong or influential for products that

75. James R. Healey, Toyota: High-tech Safety Gear for All Models Soon, USA TODAY (Sept. 4, 2014, 7:42 PM), http://www.usatoday.com/story/money/cars/2014/09/04/toyotaprecollision-safety/15068381/.

76. Id.

77. See id.

78. Hao Huang, Note, Maximizing Chinese Imports' Compliance with United States Safety and Quality Standards: Carrot and Stick From Whom?, 18 S. CAL. INTERDISC. L.J. 131, 132-33 (2008).

79. See id. at 147 . 
are not widely sold. ${ }^{80}$ Additionally, private regulation has resulted in safety improvements for global corporations, but it cannot substitute regulatory authority at the state or international level. ${ }^{81}$ This is largely because of the tension that still remains for companies aiming to gain competitive advantage: while market forces incentivize improved safety standards, the economic pressures to have low-cost production and sales simultaneously incentivize outsourcing as a means to provide reasonably priced products that consumers desire. 82 The case of Mattel provides an illustration of this tension: "Although Mattel recalled millions of Chinese-made toys in 2007, incurring economic and reputational damage, the company continues to outsource its manufacturing to China." 83 Finally, while private lawmaking does have the potential to increase safety standards, the underlying goal of this process is for companies to create safety standards that are more stringent than those of competitors-an idea that stands in stark contrast to the goal of harmonization. A global regime that increases safety standards is one goal that this proposal aims to achieve, but the other goal is harmonization, an equally important aspect of a global approach to products liability.

\section{B. Global Products Liability Through the Adoption of Voluntary Standards: Good for Harmonization, Not So Good for Increasing Safety Standards}

The idea of voluntary standards is to utilize both public and governmental actors in the market to create and publish voluntary standards, for both domestic and international companies. ${ }^{84}$ Voluntarystandard organizations, which bring together industry groups, government agencies, and consumer groups, collaborate with one

80. See Polinsky \& Shavell, supra note 40 , at 1449.

81. See David Vogel, The Private Regulation of Global Corporate Conduct: Achievements and Limitations, 49 BUS. \& SOC'Y 68, 69, 83 (2010) ("Voluntary business regulation has emerged as a response to the failures or shortcomings of existing legal mechanisms of regulatory governance in the global economy ... . But 'private approaches towards global governance are not a substitute for public policy, but rather an imperfect addition' to it." (citing Sander Chan \& Philipp Pattberg, Private Rule-Making and the Politics of Accountability: Analyzing Forest Governance, GloBal EnVTL. PoL., August 2008, at 103, 118)).

82. See Glynn, supra note 12 , at 332 .

83. Id. at 333 .

84. See generally Introduction to ANSI: Overview of the U.S. Standardization System: Voluntary Consensus Standards and Conformity Assessment Activities, ANSI, http://www.ansi.org/about_ansi/introduction/introduction.aspx?menuid=1 (last visited Nov. 17, 2014). 
another to develop safety standards for consumer products. ${ }^{85}$ While the creation and adoption of voluntary standards is a form of private lawmaking, it is different from the kind of private lawmaking discussed in Section A. The adoption of voluntary standards is like private lawmaking in that companies have the ability to play a role in the rulemaking process through involvement in the voluntary-standard organization. ${ }^{86}$ Companies may take part in the collaborative rulemaking process in order to influence the rules that are ultimately created. ${ }^{87}$ It is unlike private lawmaking in that the company does not have independent discretion to promulgate standards for itself, as the voluntary-standard organization is a collaborative effort-one that includes government agencies and consumer groups in the discussion. ${ }^{88}$ The private lawmaking discussed in Section A allows companies to essentially decide standards for themselves and implement those standards through contractual obligations, a process that does not require participation from any other interested parties. Further, voluntary standards do not inherently have the force of law like contractual provisions do. ${ }^{89}$ Government agencies may adopt these voluntary standards as mandatory standards and companies may choose to write these standards into their contracts, but without further action these standards have no inherent enforceability. 90 Finally, because many companies can and often do comply with these voluntary standards, ${ }^{91}$ adherence to these guideline often does not give companies the same competitive advantage of private lawmaking. With the private lawmaking discussed in Section A, companies may embark on bold, innovative challenges that set them apart from other competitors in the

85. Voluntary Standards, UNITED STATES CONSUMER PROD. SAFETY COMM'N, http://www.cpsc.gov/en/Regulations-Laws--Standards/Voluntary-Standards/ (last visited Nov. 17, 2014).

86. See About ANSI, ANSI, http://www.ansi.org/about_ansi/overview/overview.aspx? menuid=1 (last visited Nov. 17, 2014).

87. See Tyler R.T. Wolf, Existing in a Legal Limbo: The Precarious Legal Position of Standards-Development Organizations, 65 WASH. \& LEE L. REV. 807, 818 (2008) (discussing the potential for industry-members to influence the standards-development process).

88. See United States CONSUMER PROD. SAFETy CoMm'N, supra note 85.

89. See Lazzara, supra note 60; see also David A. Wirth, The International Organization for Standardization: Private Voluntary Standards as Swords and Shields, 36 B.C. ENVTL. AFF. L. REV. 79, 81 (2009) ("ISO standards are strictly hortatory and are not binding under international law." (citing Ira R. Feldman \& Douglas Weinfield, Environmental Management Systems, in 1 ENVIRONMENTAL LAW PRACTICE GUTdE: STATE AND FEDERAL LAW § 6A (Michael Gerrard ed., 2008)).

90. See Lazzara, supra note 60.

91. See Wirth, supra note 89 , at 83 ("ISO standards have a high profile within multinational corporations."). 
market.92 Voluntary standards, on the other hand, are open to all who wish to comply and sometimes become mandatory when they are adopted into law, so companies that choose to adhere are often on a level playing field with other competitors in the market.

Despite their shortcomings, voluntary standards are the closest thing the global market has to a "uniform" products liability regime, and it has served as an effective way to harmonize the global market. ${ }^{93}$ This harmonization is made possible by the existence of both domestic and international standard-developing organizations that work together to promote uniformity within the global market. To illustrate this dynamic, this Note examines the American National Standards Institute (ANSI) and the Internal Organization for Standardization (ISO) ${ }^{94}$

ANSI is a private, not-for-profit organization that oversees the development of voluntary standards in the United States.95 ANSI approves and accredits standards that are developed by other standards organizations, such as the American Society for Testing and Materials (ASTM). ${ }^{96}$ The mission of ANSI is "[t]o enhance both the global competitiveness of U.S. business and the U.S. quality of life by promoting and facilitating voluntary consensus standards and conformity assessment systems, and safeguarding their integrity." ${ }^{97}$ Not only does ANSI dedicate much of its work to harmonizing safety standards on a global scale, it also acts as the official U.S. representation in ISO, which is an international organization of standardizing bodies from 157 countries. ${ }^{98}$ These ISO standards are unlike any other products liability regime that exists in today's global market, as they have a potentially global reach: "[A] large proportion of the countries on the planet participate in ISO activities, and ISO standards have a high profile within multinational corporations."99

92. See, e.g., Healey, supra note 75 (discussing Toyota's innovative actions to improve the safety technology of future models).

93. See Frequently Asked Questions, ANSI, http://www.ansi.org/about_ansi/faqs/faqs. aspx?menuid=1 (last visited Nov. 17, 2014) (answering the question of "Does ANSI work only within the United States?); see also Wirth, supra note 89, at 79 ("ISO standards have a number of benefits, including promoting international uniformity.").

94. ANSI serves as the official U.S. representative to the ISO. See ANSI, supra note 93 (answering the question of "Who are ISO and IEC?").

95. See ANSI, supra note 86.

96. Robert W. Hamilton, The Role of Nongovernmental Standards in the Development of Mandatory Federal Standards Affecting Safety or Health, 56 TEx. L. REv. 1329, 1342 (1978).

97. ANSI, supra note 86.

98. See Wirth, supra note 89 , at $80-81$.

99. Id. at 83 . 
While the global harmonization potential of these voluntary standards is significant, this regime is unlikely to provide the increase in safety standards that is desirable for consumer protection. These standards involve a voluntary consensus within these standardizing bodies, which "generally means widespread acceptance after lengthy consultation." 100 ISO standards are not likely to drive industries to make improvements, and, in fact, that the ISO process produces "modest, least-common-denominator" standards is a frequently voiced concern. ${ }^{101}$ Moreover, these voluntary standards actually dissuade the creation of standards that are above and beyond the present norms: when these technical committees meet to generate voluntary consensus standards, "[i]t is not uncommon for [them] to be content with the status quo even though someone has devised something that is as good or better."102

Even though this process is not likely to increase safety standards among actors in the market, a significant strength of the voluntary standard regime is that manufacturers have often been eager to help develop and comply with voluntary standards, not only to disprove negligence or fault in product liability claims, but also to market themselves as safe and reliable within both the national and international market.103 Further, a recent study conducted and published by the Government Accountability Office ${ }^{104}$ (GAO) noted that consumer product safety experts claim that "the risk of incurring reputational and financial costs associated with product liability lawsuits provides an incentive for manufacturers to comply with voluntary standards." 105 Courts consider compliance with voluntary standards in determining negligence, fault, or the existence of a product defect, and if a manufacturer can prove compliance with these standards, this may defeat a plaintiff's claim for product defect or negligence. ${ }^{106}$

100. Id. at 87 .

101. Id.

102. Hamilton, supra note 96 , at 1376.

103. See Howells, supra note 18 , at 310 .

104. The U.S. Government Accountability Office is an independent, nonpartisan agency that supports Congress in meeting constitutional responsibilities and works to improve the performance and accountability of the federal government. See About GAO, GAO, http://gao.gov/about/index.html (last visited Nov. 17, 2014).

105. U.S. Gov'T ACCOUNTABILITY OfFICE, GAO-12-582, Consumer Product Safetry COMMISSION: A MORE ACTIVE ROLE IN VOLUNTARY STANDARDS DEVELOPMENT SHOULD BE CONSIDERED 10 (2012).

106. Id. Evidence of compliance with voluntary standards is, of course, not sufficient on its own to negate liability for the manufacturer. $I d$. at 10, n.17. 
Just as private lawmaking cannot, by itself, provide the kind of global products liability solution that the market needs, voluntary standards are not by themselves adequate for a global regime. First, these voluntary standards do not have the force of law, and governmental agencies such as the Consumer Product Safety Commission (CPSC) cannot compel compliance from manufacturers. ${ }^{107}$ In fact, legal action cannot be taken against manufacturers for noncompliance until an agency has determined that noncompliance has posed a significant risk of injury or death for consumers. ${ }^{108}$ Further, the National Commission for Product Safety ${ }^{109}$ (NCPS) has noted that in the past, voluntary industry regulation has failed to create and implement adequate safety standards, most notably because industry rarely complies with these standards to the degree necessary to ensure that only safe products are entering the market.110 To exemplify this shortcoming, the GAO noted that from 2008 to 2011,80 percent of recalls in the United States were for products that may have been subject to voluntary standards. ${ }^{111}$ The GAO also noted that certain industries actually prefer and have sought out mandatory standards for two reasons: "[F]irst, to level competition across an industry sector, especially where some manufacturers were not complying with the voluntary standard to which the rest of the industry agreed; and second, to preempt divergent state laws." 112

Furthermore, the voluntary-standard regime has the potential to create a perverse incentive: because voluntary regulations are created partly by the industry groups who comply with them, this regime may incentivize these industry groups to delay the crafting and implementing of new safety measures. ${ }^{113}$ This focus on industry may

107. $I d$.

108. See id. at $20-21$, n.30.

109. The National Commission for Product Safety was the original agency created in 1967 to assist in rulemaking for potentially hazardous goods and products. In 1972, it was replaced by the Consumer Product Safety Commission. See Anthony Sciascia, Note, Safe or Sorry: How the Precautionary Principle is Changing Europe's Consumer Safety Regulation Regime and How the United States' Consumer Product Safety Commission Must Take Notice, 58 ADMIN. L. REV. 689, 691-92 (2006).

110. See id. at 694 .

111. U.S. Gov'T ACCOUNTABILITY OFFICE, supra note 105, at 27.

112. Id. at 9 .

113. Sciascia, supra note 109, at 695, n.40 (citing Consumer Prod. Safety Comm'n Reauthorization: Hearing on H.R. 2271 and H.R. 2201 Before the Subcomm. On Health and the Env't of the H. Comm. on Energy and Commerce, 97th Cong. 63-68 (statement of Sharon Nelson, Legislative Counsel, Washington Office of Consumers Union)). 
also increase the potential for development of weaker standards ${ }^{114}$ that industry can easily comply with. In terms of international standard development, critics have also noted an accountability problem, as the international organizations that create these standards are far removed from the consumers who will ultimately be affected by their decisions. ${ }^{115}$

Finally, while the theory of harmonization resulting from these voluntary-standard organizations is promising, the reality is that these standards are not harmonized at all. In the United States, for example, there are about 400 voluntary-standard writing bodies, and the system has been described as a "hodgepodge of sources of standards rather than a neat pyramid with ANSI at the apex."116 This disorganization stands in stark contrast to the voluntary-standard regime in Europe, which requires manufacturers to comply with voluntary standards or meet the same safety requirements with a comparable approach. ${ }^{117}$ The European regime has attempted to integrate voluntary safety standards into its regulatory regime, and this approach has led to a decrease in product liability litigation. ${ }^{118}$ Once these voluntary standards become incorporated into a regulatory regime, however, they lose their voluntary nature altogether and might as well be referred to as traditional regulation. While the European approach may provide success for products liability in the domestic sense, it still leaves the global market with a lack of consistent standards across borders and a growing jumble of regulatory requirements to keep track of.

\section{A GLOBAL PRODUCTS LIABILITY REGIME TO INCREASE AND HARMONIZE SAFETY STANDARDS}

As demonstrated in Part III.A, market forces have the ability to influence private actors in the global marketplace to engage in private lawmaking that increases the safety standards for a particular product. This approach achieves the increase in safety standards that would protect consumers from the risk of unsafe products entering the market but does not achieve the harmonization that is desirable for manufacturers. Voluntary standards, which allow standard development on a global scale, can help bridge this gap by creating a single source of safety criteria for manufacturers in the global market.

114. See Lori M. Wallach, Accountable Governance in the Era of Globalization: The WTO, NAFTA, and International Harmonization of Standards, 50 U. KAN. L. REV. 823, $863(2002)$.

115. Id.

116. Hamilton, supra note 96, at 1343; see also Howells, supra note 18, at 323.

117. See Howells, supra note 18 , at 324 .

118. See id. at 345 . 
In order to create a global products liability regime that both increases and harmonizes safety standards for consumer products, this Note proposes a regime that utilizes a combination of these two private approaches. 119

The first step in instituting this regime would require that ISO (and ultimately the domestic standard-writing organizations, such as ANSI, that have a role within ISO) begin utilizing a "hard law"120 approach for the adoption of its voluntary standards. The current approach taken by ISO, which lacks inherent legal enforceability, is a form of "soft law."121 Voluntary standards exemplify the core of soft law, which requires "open, consensus, multi-stakeholder dialogue, often including government, firms, and civil society, to produce the many international standards and voluntary programmes that emerge."122 Soft law may come in the form of certification, ${ }^{123}$ and currently, parties who wish to advertise their compliance with ISO standards must go through a certification or accreditation process for the product. However, this process is initiated by companies wishing to add credibility to their products or brand, so adherence is mainly enforceable at the request of the company. ${ }^{124}$

In order to implement a hard-law approach, this Note suggests that ISO engage in private lawmaking by requiring a contractual obligation from parties who wish to advertise compliance with the voluntary standards. ${ }^{125}$ Instead of a soft-law certification process, manufacturers

119. There is an assumption in the literature that global harmonization must take place through regulatory innovation in a dominant state; however, private actors also can emerge to provide the collective response necessary to solve a transnational problem. See Abbott \& Snidal, supra note 3, at 44, 49-52.

120. Hard law "refers to legally binding obligations that are precise (or can be made precise through adjudication or the issuance of detailed regulations) and that delegate authority for interpreting and implementing the law." Gregory C. Shaffer \& Mark A. Pollack, Hard Versus Soft Law in International Security, 52 B.C. L. REv. 1147, 1160 (2011) (quoting Kenneth W. Abbott \& Duncan Snidal, Hard and Soft Law in International Governance, 54 INT'L ORG. 421, 421 (2001)).

121. See id.

122. John J. Kirton \& Michael J. Trebilcock, Introduction: Hard Choices and Soft Law in Sustainable Global Governance, in HARD CHOICES, SOFT LAW: VOLUNTARY STANDARDS in Global Trade, Environment and Social Governance 3, 22-23 (John J. Kirton \& Michael J. Trebilcock eds., 2004).

123. See id, at 22 .

124. See Certification..., ISO, http:/www.iso.org/iso/home/standards/certification.htm (last visited Nov. 17, 2014) (describing the process of certification and ISO's involvement).

125. Currently, some global corporations make adherence to ISO standards a requirement to obtain a contract, but they do not specifically write the ISO standards into their contracts. As such, a third-party's claim of ISO compliance "does not necessarily guarantee compliance with regulations." Michael E. Cloghesy, A Corporate Perspective on Globalisation, Sustainable Development, and Soft Law, in HARD CHOICES, SOFT LAW: 
will enter into a contract with the standard-writing organization, and this contract will provide baseline standards that are compliant with standards of all jurisdictions in the world and deemed "safe" by the organization. This contractual obligation will provide a compliance incentive for global manufacturers, many of whom already comply with ISO guidelines, ${ }^{126}$ because the standards written in this contract will provide assurance that any product manufactured under the stated guidelines can be sold and marketed anywhere in the world. This will provide the kind of harmonization that manufacturers desire and will lessen the risk of unsafe products entering the market. ISO can then continue its current certification process, the only difference being that when the organization finds noncompliance, this will result in a potential lawsuit for breach of contract rather than a mere refusal of certification. This contractual obligation between the standard-writing organization and the companies that comply will increase the legitimacy of voluntary standards, ${ }^{127}$ which will in turn increase the regime's chances of achieving harmonization.

The contracts drafted by the voluntary-standard organizations, such as ISO, should provide baseline safety guidelines and require that the manufacturers include these same provisions into any contracts with suppliers, buyers, or other third-party vendors. These provisions can be added into the already existing contracts with third parties, perhaps even in a separate section, and will only concern the safety standards of the products being developed. ${ }^{28}$ By mandating that manufacturers include these provisions in their third-party contracts, the proposed regime will extend the reach of these voluntary standards and ultimately protect more consumers in the global market. Because these contracts-either between the voluntary-standard organization and the manufacturer or between the manufacturer and third parties-will be entered into on a purely voluntary basis between private parties, they constitute a form of private lawmaking. ${ }^{129}$ Moreover, the competitive nature of today's global market and the ability of consumers to induce

Voluntary Standards in Global Trade, Environment and Social Governance, supra note 122 , at $323,327$.

126. See Wirth, supra note 89 , at 83.

127. See Kirton \& Trebilcock, supra note 122, at 11 ("Hard law offers the legitimacy, the strong surveillance and enforcement mechanisms, and the guaranteed resources that soft law often lacks.").

128. The provisions written into the manufacturer's contracts will have no effect on other negotiated provisions, such as choice of law, jurisdiction, waiver, notice, liability, etc. The provisions will only mandate safety requirements, the breach of which may result in legal action. Further, if a breach of safety requirements ultimately leads to consumer injury, the party who breached the requirements will be held liable.

129. See Snyder, supra note 59. 
manufacturers to improve their own safety standards will maintain a presence under this regime, as slightly altering the landscape of voluntary standards will still leave room for innovation and technological advances of manufacturers.

An additional benefit of the proposed regime is that the shortcomings of voluntary standards can be mitigated by private lawmaking. First, voluntary standards lack inherent force of law, ${ }^{130}$ but adding contractual obligations through private lawmaking will give these standards the legal authority they currently lack. Second, the perverse-incentive problem that arises in the voluntary-standard context (i.e., incentives for industry to delay crafting or implementing safety measures ${ }^{131}$ ) will be mitigated as manufacturers continue to compete with one another to implement the most innovative and hightech safety standards. ${ }^{132}$ Finally, the lack of harmonization that currently exists within the voluntary standard regime ${ }^{133}$ will no longer frustrate the ability of manufacturers to comply with these standards, as their compliance with international voluntary standards will ensure the marketability of their products in all jurisdictions around the world.

The regime proposed here is not meant to replace domestic regulation of products, but rather to supplement such regulation in an attempt to increase the safety of products entering the global stream of commerce. ${ }^{134}$ Moreover, this proposal does not set out to address all the complexities of the global market or to solve the increasing problem of recalls for imported products. ${ }^{135}$ By utilizing various forces existent in today's market, this regime exemplifies an optimistic view of the capability of global actors to institute a race-to-the-top dynamic for safety standards and compliance. Even if this regime is only capable of improving the safety of one product in today's market or one manufacturer's operation, it will still lessens the risk of harm to global consumers, and that is a worthwhile project.

130. See Lazzara, supra note 60.

131. Sciascia, supra note 109 , at 695 .

132. See, e.g., Healey, supra note 75.

133. See Howells, supra note 18 , at 323 .

134. See David Vogel, The Private Regulation of Global Corporate Conduct, in THE POLITICS OF GLOBAL REgULATION, supra note 3, at 151, 153 (explaining that, while private lawmaking cannot replace state governance, "the long-term impact of private global business regulation depends on the extent to which its standards for business conduct and its mechanisms for holding firms accountable are integrated with and reinforced by statebased regulatory policies at both the national and international levels").

135. See, e.g., Jensen, supra note 25 (discussing the increasing number of automobile recalls in 2013). 


\section{CONCLUSION}

In today's global market, the presence of TNCs and the trend to outsourcing for cheap labor and production costs have created legal complexities for manufacturers and regulators. These complexities have resulted in uncertainty among manufacturers about which laws apply to their products in the global stream of commerce, and this has ultimately placed consumer health and safety at risk at the hands of substandard or defective products. In order to eliminate this uncertainty for manufacturers while simultaneously increasing safety standards, a products liability regime that utilizes private lawmaking should be introduced into the global market. By utilizing the most effective aspects of voluntary standards and supplementing those standards with private contractual lawmaking, the global market has the ability to both harmonize and increase safety standards around the globe. In doing so, the market will lessen the risk of injury or harm to consumers, thus making today's global market much safer and more reliable than before. 